\title{
Formation and disclosure of information on social responsibility of agribusiness enterprises
}

\author{
Dzhaudat Faizrakhmanov ${ }^{1,}{ }^{*}$, Alsou Zakirova ${ }^{1}$, Guzaliya Klychova ${ }^{1}$, Alfiya Yusupova $^{2}$ and \\ Aigul Klychova ${ }^{1}$ \\ ${ }^{1}$ Kazan State Agrarian University, Ferma-2 st. 53, Kazan, 420015, Kazan, Russia \\ ${ }^{2}$ Russian Islamic Institute, Gazovaya ul., 19, 420049, Kazan, Russia
}

\begin{abstract}
The purpose of the article is to substantiate theoretical provisions and develop practical recommendations for the formation and disclosure of information on social responsibility of enterprises in the agrarian sphere of economy. The research objectives are as follows: to study and specify the economic essence of the notion of "corporate social responsibility", to substantiate theoretical foundations and propose new methodological approaches of corporate social responsibility assessment and the formation of social reporting. The essence and content of corporate social responsibility, principles of formation and structure of the social report are studied with the help of such general scientific methods as systematic approach, comparison, economic-statistical method and data systematization and generalization method. The paper presents the main sections subject to including in the social report and suggests forms of social reporting, which include key performance indicators which help to assess the socio-economic performance of organizations in the agrarian sector of economy.
\end{abstract}

\section{Introduction}

At present, many business representatives have come to realize that it is necessary to develop sustainable enterprises that combine economic, social and environmental factors in order to reduce business risks, strengthen competitiveness, increase staff efficiency and customer loyalty, improve the goodwill of companies, make a positive contribution of entrepreneurship to the social and economic development of their territories. This contributes to the creation of favorable conditions for the implementation of long-term business development strategies based on the balance of interests of the interacting parties.

To achieve sustainable development of companies, it is necessary to effectively manage the socially responsible business and evaluate its efficiency.

In modern conditions, corporate social responsibility is one of the most important areas of the company activity management; and the implementation of social investments is one of the key indicators of the social responsibility of business. The implementation of social policy by large enterprises is an indispensable factor directly affecting economic efficiency of activity. Recently, the social component of business has become increasingly important both

*Corresponding author:kgaukgs@mail.ru 
for organizations and a society as a whole, as many years of experience show that enterprises developing their socially-oriented activities are more trusted by the state, investors, contractors, creditors and other business partners. Social responsibility of business contributes to minimizing the negative impact of the enterprise's production activity, creating an atmosphere of trust, predictability and common values in society, which makes business more economically and socially sustainable. In this respect, relevant issues are related to the assessment of the social responsibility of the enterprise level, determining the main directions of social development of companies.

Main factors contributing to the social responsibility of business increase include harmonization of social relations, support of human capital replenishment processes; more complete satisfaction of a wide range of human and social needs, economic growth and successful reproduction of economic capital, social contradictions settlement, maintaining and strengthening the social stability in the society.

\section{Materials and Methods}

Currently, the uniform definition of the concept of "corporate social responsibility" lacks in the international practice. This term implies the idea according to which the companies shall take into account the interests of the community, bearing responsibility for the impact of their activity on workers, shareholders, contractors, local communities, on the environmental conditions. Corporate social responsibility implies compliance on the part of the business entities with rules and norms that are uncertain or implicitly defined by legislation in the field of ecology, ethics, philanthropy, charity, etc. $[1,3]$.

Analyzing the social responsibility of business structures, it should be noted that most enterprises in the agrarian sphere of economy lack a clear understanding of what is meant by social responsibility and the tools for its formation. Despite the fact that more and more enterprises are carrying out their own social and charitable initiatives, the participation of business structures in the process of local problems in the social sphere settlement is, as a rule, non-systemic and limited in scope and time. The main driving force promoting the development of promising practices of corporate social responsibility are medium and large business structures, for which, compared to small businesses, the reputation component is much more important $[4,7]$.

From the point of view of Russian entrepreneurship, the need to introduce corporate social responsibility practices is determined by two factors: on the one part, business risks are minimized as a result of overcoming contradictions with stakeholders; on the other part, it is possible to transform the problems existing in the social, environmental and economic spheres into opportunities for their business [10]. As a result, the enterprise, positioning itself as an independent and effective subject of corporate social responsibility, can form a stable positive reputation, which will promote the growth of trust and increase the value of business [14].

Measures implemented by enterprises within the framework of corporate social responsibility can be reflected in social programs and published in social reporting. Based on this, the following advantages of implementing the strategy of corporate social responsibility can be revealed:

- Management of projects is systematized and the relationship between the programs are being implemented and the organization's strategy is provided [6];

- Cooperation with stakeholders on efficient use of the company's available resources is systematized [2];

- Management decisions are supported on the basis of improving the system of internal non-financial reporting [8]; 
- Information transparency of the enterprise is increased, its reputation in the international and Russian markets being strengthened;

- Confidence of stakeholders operating in the region is strengthened;

- Improved image of the enterprise.

The efficiency of corporate social programs is achieved through:

- Clear formulation of the internal corporate social strategy, development and implementation of social programs jointly with public authorities, by independent consultants [15];

- Commitment to achieve a significant social result on the basis of compliance with the business interests of the company;

- Innovations in the field of social technologies and reforms support [17];

- Use of the modern management mechanisms - competitive allocation of funds, equity financing, implementation of monitoring and evaluation of socio-economic results.

Development and implementation of business plan shall be carried out in the following stages: the investment attractiveness of the industry is analyzed; a scenario forecast of the industrial development is elaborated [12]; changes in demand and supply in foreign and domestic markets are forecasted; the competitive position of the enterprise in the industry is analyzed; strategic alternatives are evaluated; strategic goals and objectives are being developed $[13,16]$.

Special attention should be paid to issues related to the evaluation and implementation of social responsibility.

The evaluation of corporate social responsibility shall be carried out in the following directions: results of activity in the field of sustainable development; economic performance; environmental responsibility; social responsibility.

The social report serves is one of the tools contributing to the quality improvement of planning, monitoring and evaluation of socio-economic activity in the organization. It is a voluntary reporting form disclosing information on the main aspects and results of the social and economic activity in the company related to the strategy of sustainable business development [18]. The social report shall reflect reliable and accessible data for the main interested users on the company's social responsibility towards society [20]. Disclosing information on social responsibility and corporate governance in the reporting, the company attracts investors, as it is possible to reduce the risks of inefficient financial investments and to provide additional financing for planned business development activity on the basis of non-financial information [11]. Thus, non-financial information allows the shareholders and other interested parties to get an objective view of the current situation and prospects of business development [19].

At the same time, it should be noted that most of the Russian enterprises fail to disclose non-financial information to the full extent, including corporate governance issues [9]. This is explained primarily by the financial costs which are required for its drawing up.

Despite this, in the practice of social reports forming by large Russian corporations, there is a certain tendency to gradually improve the disclosure of non-financial information in accordance with international standards of social reporting.

Two groups of social reporting, external and internal are being specified. External social reporting reflects such data as costs associated with social activities; expenses for the improvement of the territories belonging to the enterprise; expenses for environmental protection; expenses for creating new jobs. Internal social reporting reflects the costs allocated to social support for employees and their families; expenses for the improvement of the workplace and everyday life of the employees of the enterprise; expenses related to payment of additional pensions to former employees; the amount of beneficial loans provided to the employees of the enterprise. 


\section{Results}

Main principles for the corporate social reporting formation are the following:

1. The principle of information wealth means that the social reporting shall reflect the data accounting the opinions and interests of all parties concerned in the social initiatives of the organization.

2. The principle of compatibility implies that social reporting reflect indicators which are basic at assessing and comparing the activity of various enterprises, studying the dynamics of the social responsibility of the enterprise development for certain periods of time and comparing the levels of social responsibility of different organizations.

3 . The principle of expediency and regularity consists in regular revision of social projects carried out by the enterprise.

4. The principle of consistency contributes to the compatibility of the company's social responsibility indicators.

6 . The principle of expediency supposes the correct choice of the period for the formation of social reporting with a view to exercising operational control over the activity of the organization.

9. The principle of constructivity means that the formation of social reporting shall not be limited only by reflecting the state of social activity, but also shall contribute to the development of measures that are aimed at consolidating positive achievements in the company's activity.

11. The principle of essentiality consists in the need to rank the events which form the basis of the report in terms of their relevance to both the organization and interested parties.

In our opinion, social reporting shall include the following sections:

1. The strategy of the organization activity;

The strategic priorities of the organization's activity in the agrarian sphere of economy are the following: innovative development and the use of new technologies for the purposes of production efficiency improvement; implementation of measures optimizing the cost structure at all stages of production activity; compliance with environmental safety standards; maintenance and development of personnel; measures ensuring safe working conditions; social responsibility of business in the regions of its operation (creation of jobs, payment of taxes to local budgets, support of local public authorities in financing of social programs); expansion of the reliable clients database.

2. Functional structure of the organization;

3. Types of activity, organizational and legal form, the scale of the organization;

4. Management structure;

5. Changes in the structure, scope, form of the organization ownership in the reporting period;

6. Business processes;

7. Interaction with stakeholders;

The essentiality principle shall be applied to determine the main groups of stakeholders. This criterion allows assessing the impact of the organization on the stakeholders, as well as their impact on the sustainability and performance of the organization.

8. Innovative development of the organization involves: improvement of energy efficiency; increase of ecological compatibility of production; mastering of new technology in production; creation and development of research infrastructure; improvement of innovative and business processes management.

Key indicators of innovative activity efficiency shall be reflected in a separate social report (SR) (Table 1). 
Table 1. SR-1. Key indicators of innovative activity efficiency.

\begin{tabular}{|l|c|c|}
\hline \multicolumn{1}{|c|}{ Indicator } & \multicolumn{2}{|c|}{ Year } \\
\cline { 2 - 3 } & plan & realization \\
\hline $\begin{array}{l}\text { Share of expenses, connected with research and development of } \\
\text { technology in the total volume of expenses, \% }\end{array}$ & 1.12 & 1.14 \\
\hline $\begin{array}{l}\text { Share of expenses for purchasing of innovative products in the total } \\
\text { volume of expenses, \% }\end{array}$ & 0.71 & 0.82 \\
\hline $\begin{array}{l}\text { Share of expenses for implementation/application of R\&D results, } \\
\text { new technology and new appliances, \% }\end{array}$ & 0.43 & 0.44 \\
\hline $\begin{array}{l}\text { Share of expenses for power in the structure of total cost of product } \\
\text { in the structure of the total cost of product \% }\end{array}$ & 11.3 & 12.6 \\
\hline $\begin{array}{l}\text { Energy resources consumption for manufacturing of agricultural } \\
\text { product unit GJ/kg }\end{array}$ & 0.210 & 0.216 \\
\hline $\begin{array}{l}\text { Water consumption for manufacturing of agricultural product unit } \\
\text { thous. } \mathrm{m}^{3} / \mathrm{kg}\end{array}$ & 0.09 & 0.094 \\
\hline $\begin{array}{l}\text { Specific indicator of greenhouse gases emissions in eq. CO }{ }^{2} \text { by the } \\
\text { mobile and fixed sources per unit of product, ton/kg }\end{array}$ & 0.0011 & 0.0012 \\
\hline Economic effect of R\&D implementation, mln rub. & 2.78 & 2.81 \\
\hline Share of innovative products in the total sales volume, \% & 0.9 & 0.96 \\
\hline
\end{tabular}

9. Economic efficiency indicators;

Economic performance of enterprises of the agrarian sector of economy involves stability and efficiency provision by increasing the competitiveness of products; increase of investment attractiveness and capitalization of the enterprise; participation in sustainability provision of sectoral, regional, Russian and global socio-economic systems [5].

It is advisable to use the system of indicators presented in the social report for assessing the economic performance. (Table 2).

Table 2. SR-2. Key indicators of economic efficiency.

\begin{tabular}{|l|c|c|}
\hline \multirow{2}{*}{ Indicators } & \multicolumn{2}{|c|}{ Years } \\
\cline { 2 - 3 } & 2015 & 2016 \\
\hline $\begin{array}{l}\text { Gross product value in compatible prices of 1994 as calculated: } \\
\text { - per 100 ha of agricultural area, thous.rub. }\end{array}$ & 53.4 & 50.5 \\
\hline - per 1 average year employee, thous.rub. & 17.6 & 16.7 \\
\hline - per 100 rub. BPA, rub. & 3.9 & 3.5 \\
\hline - per 100 rub. Of production expenses & 2.2 & 2.3 \\
\hline $\begin{array}{l}\text { Gross revenue value as calculated: } \\
\text { - per 100 ha of agricultural lands, thous.rub. }\end{array}$ & 834.0 & 900.8 \\
\hline - per 1 average year employee, thous.rub. & 429.6 & 398.4 \\
\hline - per 100 rub. BPF, rub. & 64.8 & 72.3 \\
\hline - per 100 rub. Of production costs & 54.7 & 55.5 \\
\hline $\begin{array}{l}\text { Revenue value, losses as calculated: } \\
\text { - per 100 ha of agricultural lands, thous.rub. }\end{array}$ & 39.7 & 43.5 \\
\hline - per 1 average year employee, thous.rub. & 3,2 & 14,4 \\
\hline - per 100 rub. BPF, rub. & 2,7 & 2,9 \\
\hline - per 100 rub. Of production costs & 0.4 & 2.0 \\
\hline Profitability level (+), loss ratio (-), & 0.73 & 0.43 \\
\hline Profit margin, \% & 1.86 & 1.35 \\
\hline
\end{tabular}

10. Nature protection activity indicators

Agricultural enterprise must annually finance environmental activities, thus making a contribution into a sustainable development and formation of necessary conditions for ensuring the future environmental well-being. Information on the costs of nature protection activity implementing shall be provided in the social report (Table 3) 
Table 3. SR - 3 "Distribution of expenses for environmental protection» (thousand rubles).

\begin{tabular}{|l|c|c|}
\hline \multicolumn{1}{|c|}{ Indicator } & \multicolumn{2}{c|}{ Year } \\
\cline { 2 - 3 } & plan & realization \\
\hline Current (operational) costs, including: & 1128.3 & 1168.2 \\
\hline $\begin{array}{l}\text { - atmosphere protection and climate change prevention } \\
\text { costs }\end{array}$ & 457.1 & 469.7 \\
\hline - sewage waters collection and purification costs & 3614 & 384.3 \\
\hline - wastes disposal costs & 176.2 & 179.4 \\
\hline $\begin{array}{l}\text { - costs for protection and reclamation of lands, } \\
\text { underground and surface waters }\end{array}$ & 74.7 & 75.1 \\
\hline $\begin{array}{l}\text { - costs for biodiversity preservation and protection of } \\
\text { natural reserves }\end{array}$ & 58.9 & 59.7 \\
\hline Costs for nature protection services & 34.8 & 36.2 \\
\hline $\begin{array}{l}\text { Costs for capital repair of fixed assets of nature } \\
\text { protection purposes }\end{array}$ & 253.7 & 254.8 \\
\hline Investments in capital assets & 1542.9 & 1601.3 \\
\hline
\end{tabular}

When carrying out production activity, agricultural organizations shall strive to reduce the anthropogenic burden of wastes on the environment. Main activities aimed at the decrease of the negative impact on the environment involve reduction of the wastes volume due to their use in economic activity and use of modern technology for wastes decontamination.

11. Indicators of human rights performance.

An effective personnel policy of an agricultural organization is characterized by the formation of competent and highly qualified personnel, effective use of the personnel reserve, provision of employees with favorable working conditions and equal opportunities for realization of their potential and professional abilities. Main tasks in the field of personnel management involve preservation and reproduction of qualified personnel; improvement of selection and staffing system; improvement of the personnel assessment system, improvement of labor motivation system, improvement of work on the personnel reserve formation, provision of career growth and promotion of young professionals.

It is necessary to apply a progressive wage system which involves interrelation with the results of work, transparency and fairness, competitiveness of wages for high competitiveness maintaining, attracting and retaining highly qualified and motivated employees. Realizing the monitoring of changes in social and economic conditions (inflation and labor market situation), the organization shall make a decision on the indexation of wages. Also, the main criteria for the social responsibility of the organization include the creation of safe working conditions. At the same time, the organization shall reduce the risk in the workplace, prevent accidents at work and achieve a high level of safety and labor protection. Implementation of these tasks can be ensured by the implementation of a safety management system, labor and environmental protection which meets the requirements of international ISO standards. The social report presented in Table 4 shall be used to reflect human rights performance indicators.

Table 4. SR - 4 "Indicators characterizing the efficiency of policy in the field of personnel management".

\begin{tabular}{|l|c|c|}
\hline \multicolumn{1}{|c|}{ Indicator } & \multicolumn{2}{c|}{ Years } \\
\cline { 2 - 3 } & \multicolumn{1}{|c|}{2015} & 2016 \\
\hline $\begin{array}{l}\text { Costs for labor safety and protection, risk of accidents and } \\
\text { unscheduled losses decrease (thousand rub.), including }\end{array}$ & 1070.7 & 1073.0 \\
\hline Industrial accidents level & & \\
\hline - number of accidents & 1 & - \\
\hline - including resulting in death & - & - \\
\hline
\end{tabular}




\begin{tabular}{|l|l|l|}
\hline $\begin{array}{l}\text { Expenses volume, allocated for labor protection, as calculated per } \\
\text { one employee, rub. }\end{array}$ & 1573 & 1589 \\
\hline Average annual hours for training of one staff employee & 54 & 56 \\
\hline Costs for training of one staff employee, thous. rub. & 7.23 & 7.31 \\
\hline
\end{tabular}

12. Indicators of activities in the field of interaction with society.

Activity of the company related to interaction with the society are based on maintenance and development of local communities, social investments direction into the regions of its operation, provision of charity and sponsorship, interaction with trade unions, and implementation of youth policy (Table 5).

Table 5. SR - 5 "Indicators characterizing the efficiency of activities in the field of interaction with the society".

\begin{tabular}{|l|c|c|}
\hline \multicolumn{1}{|c|}{ Indicator } & \multicolumn{2}{c|}{ Years } \\
\cline { 2 - 3 } & 2015 & 2016 \\
\hline Costs for socio-economic development of a region, thous. rub. & 2741.6 & 2802.3 \\
\hline $\begin{array}{l}\text { Costs for charitable assistance in culture, education, sport, health } \\
\text { care. }\end{array}$ & 3514.8 & 3567.2 \\
\hline Costs for youth policy implementation & 1278.4 & 1305.8 \\
\hline $\begin{array}{l}\text { Number of control checks of labor conditions, compliance with } \\
\text { legislation on labor protection, collective agreements fulfillment and } \\
\text { labor protection agreements }\end{array}$ & 3 & 3 \\
\hline
\end{tabular}

The main advantage of reporting is its availability to all interested users. Social reporting is an effective tool improving the image and reputation, increasing trust, quality, reliability and transparency in customer relationships; promoting brand recognition and investment in the environment, community, human capital; improving the quality of business management, competitiveness and quality of products; increases the attractiveness in the eyes of consumers due to the implementation of socially significant activity; improving the efficiency of personnel management and charitable activities; ensuring the environmental protection and conservation of natural resources.

\section{Conclusions}

Thus, doing the socially responsible business will make the enterprise more significant, for the region, increase consumer confidence, and as a result, increase consumption, make the enterprise attractive in the eyes of investors, enabling to expand production, increase the competitiveness of the enterprise, implement innovative technologies in production, turn new developments into the industrial standard, especially concerning the protection of the environment and product quality, which will enable to develop competitiveness and create barriers for other producers, forcing them to grow to the production leader's level, will help to strengthen the corporate spirit and corporate ethics, reduce staff turnover, increase employees' interest in the efficiency of the enterprise's activity, and as a consequence this will be expressed as labor quality, volumes of production and quality of products.

\section{References}

1. B.A. Al-Gamrh, R.A. AL-Dhamari, International Business Management 10, 4283-4291 (2016)

2. B. Letsoalo, J. Coetzee, W. Ukpere, Mediterranean Journal of Social Sciences 5(1), January (2014) 
3. N. Boeger, R. Murray, C. Villiers, Perspectives on Corporate Social Responsibility (Edward Elgar Publishing, 2008)

4. C.P. Teixeira, Mediterranean Journal of Social Sciences 4(9), 356-375 (2013)

5. G.S. Klychova, A.R. Zakirova, K.Z. Mukhamedzyanov, E.R. Sadrieva, A.S. Klychova, Journal of Engineering and Applied Sciences 12, 4966-4973 (2017)

6. G.N. Neluheni, W. Pretorius, W.I. Ukpere, Mediterranean Journal of Social Sciences 5(1), January (2014)

7. K.M. Khatun, Md.A. Islam, I. Md. Noor, S. Sa `aban, The Social Sciences 10, 166-170 (2015)

8. G.S. Klychova, A.R. Zakirova, E.R. Kamilova, International Business Management 10, 5254-5260 (2016)

9. G.S. Klychova, A.R. Zakirova, Z.R. Zakirov, G.R. Valieva, Asian Social Science 11(11), 308-312 (2015)

10. G.S. Klychova, B.G. Ziganshin, A.R. Zakirova, G.R. Valieva, A.S. Klychova, Journal of Engineering and Applied Sciences 12, 4958-4965 (2017)

11. G.S. Klychova, D.I. Faizrakhmanov, A.R. Zakirova, E.R. Sadrieva, Asian Social Science 11(11), 302-307 (2015)

12. K. McElhaney, A strategic approach to corporate social responsibility. Leader to Leader 52(1), 30-36 (2009)

13. M. Hossein, Z. Arani, The Effect of Corporate Governance Mechanisms on Social Responsibility Disclosure 7(4), S2 (2016)

14. M.M. Nizamutdinov, G.S. Klychova, L.M. Mavlieva, L.N. Safiullin, Mediterranean Journal of Social Sciences 5(18), 215-218 (2014)

15. L.N. Safiullin, G.S. Klychova, A.S. Klychova, Mediterranean Journal of Social Sciences 5(18), 183-186 (2014)

16. I. Sergeeva, Asian Social Science 11(6), 144-149 (2015)

17. S. Che, X. Li, Asian Social Science 11(24), 185-191 (2015)

18. E.U. Strelnik, D.S. Usanova, I.G. Khairullin, G.I. Shafigullina, K.T. Khairullina, Journal of Engineering and Applied Sciences 12, 4899-4904 (2017)

19. E.N. Fakhretdinova, G.S. Klychova, A.S. Klychova, N.V. Antonova, Asian Social Science 11(11), 318-322 (2015) 